\title{
Assessment of Undiscovered Oil and Gas Resources in the Eagle Ford Group and Associated Cenomanian-Turonian Strata, U.S. Gulf Coast, Texas, 2018
}

Using a geology-based assessment methodology, the U.S. Geological Survey estimated undiscovered, technically recoverable mean resources of 8.5 billion barrels of oil and 66 trillion cubic feet of gas in continuous accumulations in the Upper Cretaceous Eagle Ford Group and associated Cenomanian-Turonian strata in onshore lands of the U.S. Gulf Coast region, Texas.

\section{Introduction}

The U.S. Geological Survey (USGS) assessed undiscovered, technically recoverable hydrocarbon resources in self-sourced continuous reservoirs of the Upper Cretaceous Eagle Ford Group and associated Cenomanian-Turonian strata, which are present in the subsurface across the U.S. Gulf Coast region, Texas (fig. 1). The USGS completes geologybased assessments using the elements of the total petroleum system (TPS), which include source rock thickness, organic richness, and thermal maturity for self-sourced continuous accumulations. Assessment units (AUs) within a TPS are defined by strata that share similar structural and petroleum-charge histories along with lithology and stratigraphy.

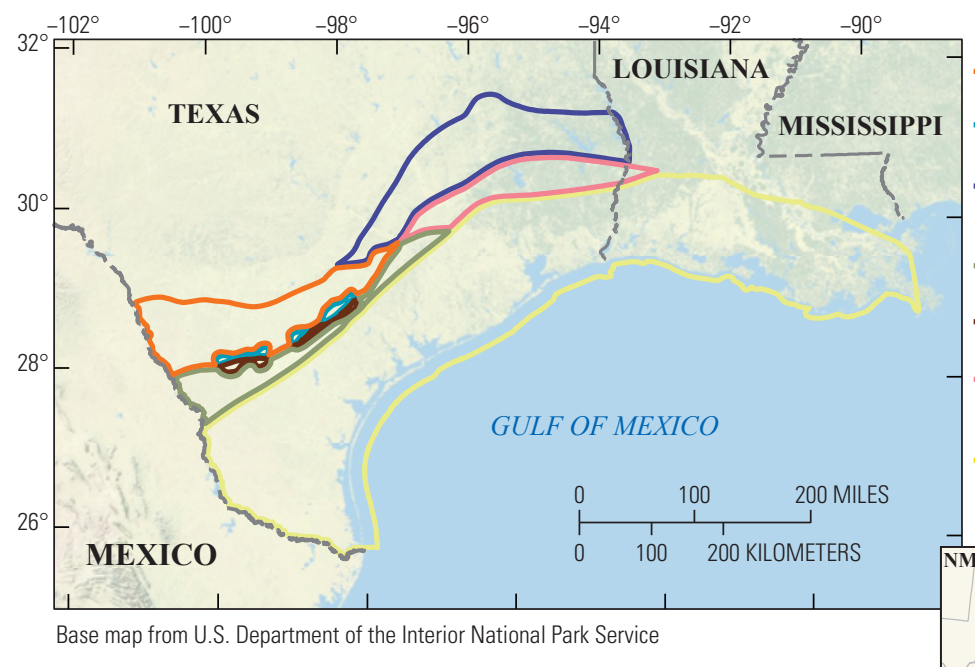

Figure 1. Map showing the extent of the seven assessment units (AUs) in the Eagle Ford Group and associated CenomanianTuronian strata in the U.S. Gulf Coast region, Texas.
EXPLANATION

Eagle Ford Marl Continuous Oil AU Submarine Plateau-Karnes Trough Continuous Oil AU Cenomanian-Turonian Mudstone Continuous Oil AU

Eagle Ford Marl Continuous Gas AU

Submarine Plateau-Karnes Trough Continuous Gas AU Cenomanian-Turonian Mudstone Continuous Gas AU Cenomanian-Turonian Downdip Continuous Gas AU

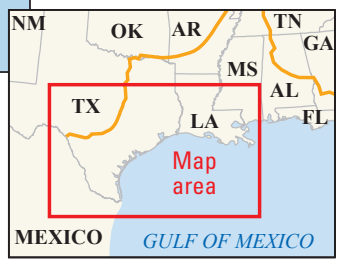
Upper Jurassic-Cretaceous-Tertiary Composite Total Petroleum System boundary (part) shown in orange.

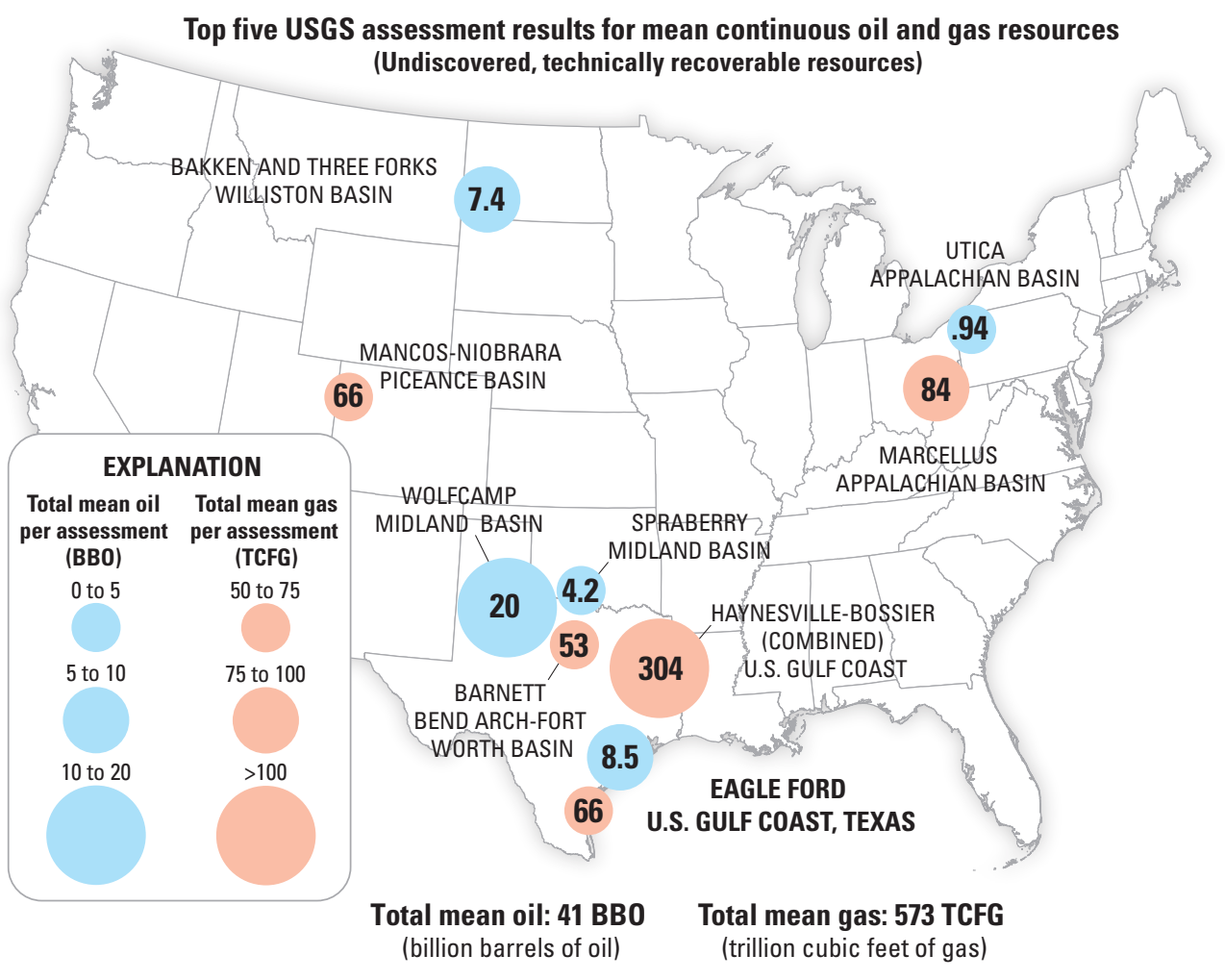

Total Petroleum System and Geologic Models for Assessment

The Eagle Ford Group contains one of the most prolific continuous accumulations of oil and gas in the United States (fig. 2); its composition is predominantly mudstone and calcareous mudstone (marl) with organic-rich intervals. These marine strata were deposited in outer shelf and upper slope environments during the Cenomanian-Turonian ages (Denne and Breyer, 2016). The assessed rock interval

Figure 2. Bubble map showing the relative sizes of the top five U.S. Geological Survey assessment results through 2018 for continuous oil and gas resources in the United States. Quantitative assessment results are from Coleman and others (2011), Kirschbaum and others (2012), Gaswirth and others $(2013,2016)$, Marra and others $(2015,2017)$, Hawkins and others (2016), and Paxton and others (2017a, b). 
includes mudstone strata that may be slightly older than Eagle Ford Group strata but are not well understood in terms of age or distribution. Therefore, these units are referred to as "associated CenomanianTuronian strata." To better capture the resource heterogeneity of this interval, Eagle Ford Group marl strata are defined as having less than 25 percent clay, and Cenomanian-Turonian mudstone strata are defined as having more than 25 percent clay, based on work by Donovan and others (2017). The Eagle Ford Group and associated Cenomanian-Turonian strata are part of the Upper Jurassic-CretaceousTertiary Composite TPS in onshore lands of the U.S. Gulf Coast region, Texas (Dubiel and others, 2012).

\section{Assessment Units}

Seven continuous AUs (fig. 1) were defined for the Eagle Ford Group and associated Cenomanian-Turonian strata across the study area, based on lithology, stratal thickness, thermal maturity, regional geologic features, and spatial distribution of productive fairways.

The Eagle Ford Marl Continuous Oil AU is defined by the United StatesMexico border, the 25-percent-clay line, and the thermal maturity window for oil (0.6-1.3 percent modeled vitrinite reflectance) (fig. 1). Within this AU is the Submarine Plateau-Karnes Trough Continuous Oil AU, which is an area of thicker Eagle Ford Group strata (greater than 120 feet), as mapped by Hammes and others (2016) (fig. 1). The thicker interval is interpreted to have provided additional source rock and reservoir potential. The CenomanianTuronian Mudstone Continuous Oil AU is bounded by the 25-percent-clay line, the eastern extent of production of Cenomanian-Turonian oil (at about the Texas-Louisiana State line), and the thermal maturity window for oil (0.6-1.3 percent modeled vitrinite reflectance) (fig. 1).

The Eagle Ford Marl Continuous Gas AU is defined by the United
States-Mexico border, the 25-percent-clay line, the updip limit of gas generation (1.3 percent modeled vitrinite reflectance), and the Lower Cretaceous shelf margin as illustrated by Donovan and others (2015) (fig. 1). The Submarine Plateau-Karnes Trough Continuous Gas AU is defined as the area within the Eagle Ford Marl Continuous Gas AU that has Eagle Ford Group strata greater than 120 feet thick, which is interpreted to have additional source rock and reservoir potential. The CenomanianTuronian Mudstone Continuous Gas AU is defined by the 25-percent-clay line, the updip limit of gas generation (1.3 percent modeled vitrinite reflectance), and the outboard expression of the Upper Cretaceous shelf margin as illustrated by Galloway (2008) (fig. 1). The Cenomanian-Turonian Downdip Continuous Gas AU (fig. 1), which extends to the State-Federal waters boundary, was not quantitatively assessed because of a lack of data.

Table 1 lists input data used to calculate undiscovered resources in the six quantitatively assessed AUs.

Table 1. Key input data for six assessment units in the Eagle Ford Group and associated Cenomanian-Turonian strata in the U.S. Gulf Coast region, Texas.

[AU, assessment unit; \%, percent; EUR, estimated ultimate recovery per well; MMBO, million barrels of oil; BCFG, billion barrels of gas. The average EUR input is the minimum, median, maximum, and calculated mean. Shading indicates not applicable]

\begin{tabular}{|c|c|c|c|c|c|c|c|c|}
\hline \multirow{2}{*}{$\begin{array}{l}\text { Assessment input data- } \\
\text { Continuous AUs }\end{array}$} & \multicolumn{4}{|c|}{ Eagle Ford Marl Continuous Oil AU } & \multicolumn{4}{|c|}{ Submarine Plateau-Karnes Trough Continuous Oil AU } \\
\hline & Minimum & Mode & Maximum & $\begin{array}{c}\text { Calculated } \\
\text { mean }\end{array}$ & Minimum & Mode & Maximum & $\begin{array}{c}\text { Calculated } \\
\text { mean }\end{array}$ \\
\hline Potential production area of AU (acres) & $3,783,000$ & $5,021,000$ & $5,661,000$ & $4,821,667$ & 320,000 & 406,000 & 497,000 & 407,667 \\
\hline Average drainage area of wells (acres) & 60 & 100 & 120 & 93.3 & 60 & 100 & 120 & 93.3 \\
\hline Percentage of area untested in AU & 63 & 73 & 76 & 70.7 & 4 & 22 & 36 & 20.7 \\
\hline Success ratio $(\%)$ & 85 & 90 & 95 & 90 & 95 & 97 & 99 & 97 \\
\hline Average EUR (MMBO) & 0.05 & 0.15 & 0.3 & 0.156 & 0.11 & 0.2 & 0.35 & 0.207 \\
\hline AU probability & 1.0 & & & & 1.0 & & & \\
\hline \multirow{2}{*}{$\begin{array}{l}\text { Assessment input data- } \\
\text { Continuous AUs }\end{array}$} & \multicolumn{4}{|c|}{ Cenomanian-Turonian Mudstone Continuous Oil AU } & \multicolumn{4}{|c|}{ Eagle Ford Marl Continuous Gas AU } \\
\hline & Minimum & Mode & Maximum & $\begin{array}{c}\text { Calculated } \\
\text { mean }\end{array}$ & Minimum & Mode & Maximum & $\begin{array}{c}\text { Calculated } \\
\text { mean }\end{array}$ \\
\hline Potential production area of AU (acres) & $2,600,000$ & $4,210,000$ & $7,270,000$ & $4,693,333$ & $1,100,000$ & $2,000,000$ & $2,850,000$ & $1,983,333$ \\
\hline Average drainage area of wells (acres) & 80 & 120 & 140 & 113.3 & 80 & 120 & 140 & 113.3 \\
\hline Percentage of area untested in $\mathrm{AU}$ & 97 & 98 & 99 & 98 & 88 & 93 & 95 & 92 \\
\hline Success ratio $(\%)$ & 50 & 70 & 90 & 70 & 80 & 85 & 90 & 85 \\
\hline Average EUR (MMBO, oil; BCFG, gas) & 0.01 & 0.11 & 0.2 & 0.113 & 1 & 2.5 & 4.5 & 2.579 \\
\hline AU probability & 1.0 & & & & 1.0 & & & \\
\hline \multirow{2}{*}{$\begin{array}{l}\text { Assessment input data- } \\
\text { Continuous AUs }\end{array}$} & \multicolumn{4}{|c|}{ Submarine Plateau-Karnes Trough Continuous Gas AU } & \multicolumn{4}{|c|}{ Cenomanian-Turonian Mudstone Continuous Gas AU } \\
\hline & Minimum & Mode & Maximum & $\begin{array}{c}\text { Calculated } \\
\text { mean }\end{array}$ & Minimum & Mode & Maximum & $\begin{array}{c}\text { Calculated } \\
\text { mean }\end{array}$ \\
\hline Potential production area of AU (acres) & 270,000 & 372,000 & 436,000 & 359,333 & 1,000 & $1,500,000$ & $3,000,000$ & $1,500,333$ \\
\hline Average drainage area of wells (acres) & 80 & 120 & 140 & 113.3 & 120 & 140 & 160 & 140 \\
\hline Percentage of area untested in AU & 84 & 88 & 90 & 87.3 & 100 & 100 & 100 & 100 \\
\hline Success ratio $(\%)$ & 90 & 95 & 99 & 94.7 & 10 & 50 & 90 & 50 \\
\hline Average EUR (BCFG) & 1.5 & 3 & 5 & 3.079 & 0.3 & 0.9 & 3 & 1.012 \\
\hline AU probability & 1.0 & & & & 1.0 & & & \\
\hline
\end{tabular}




\section{Undiscovered Resources Summary}

The USGS assessed undiscovered, technically recoverable oil and gas resources for six continuous AUs in the Eagle Ford Group and associated CenomanianTuronian strata, U.S. Gulf Coast region, Texas (table 2). The estimated mean totals for oil and gas resources in the Eagle Ford Marl, Submarine Plateau-Karnes Trough, and Cenomanian-Turonian Mudstone Continuous Oil and Gas AUs are 8,515 million barrels of oil (MMBO), or 8.5 billion barrels of oil, with an F95-F5 range from 5,266 to $12,846 \mathrm{MMBO} ; 65,981$ billion cubic feet of gas (BCFG), or 66 trillion cubic feet of gas, with an F95-F5 range from 37,984 to 104,048 BCFG; and 1,891 million barrels of natural gas liquids (MMBNGL) with an F95-F5 range from 1,032 to 3,093 MMBNGL (table 2). These assessment results for the Eagle Ford Group and associated CenomanianTuronian strata are among the top five largest continuous resources for both oil and gas assessed by the USGS in the United States (fig. 2).

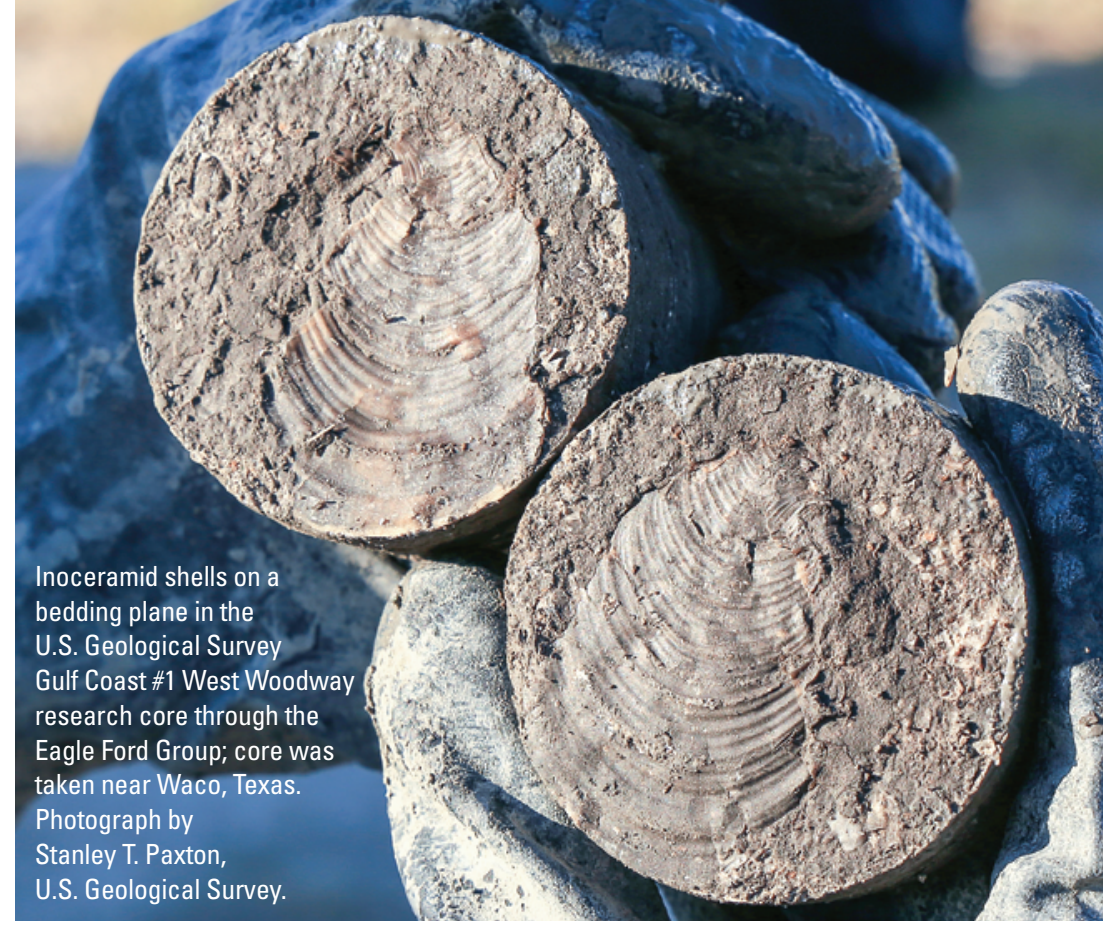

Table 2. Results for six assessment units in the Eagle Ford Group and associated Cenomanian-Turonian strata in the U.S. Gulf Coast region, Texas.

[MMBO, million barrels of oil; BCFG, billion cubic feet of gas; NGL, natural gas liquids; MMBNGL, million barrels of natural gas liquids. Results shown are fully risked estimates. F95 represents a 95-percent chance of at least the amount tabulated; other fractiles are defined similarly. Fractiles are additive under the assumption of perfect positive correlation. Shading indicates not applicable]

\begin{tabular}{|c|c|c|c|c|c|c|c|c|c|c|c|c|c|c|}
\hline \multirow{3}{*}{$\begin{array}{l}\text { Total petroleum system } \\
\text { and assessment units (AUs) }\end{array}$} & \multirow{3}{*}{$\begin{array}{c}\text { AU } \\
\text { prob- } \\
\text { ability }\end{array}$} & \multirow{3}{*}{$\begin{array}{c}\text { Accu- } \\
\text { mulation } \\
\text { type }\end{array}$} & \multicolumn{12}{|c|}{ Total undiscovered resources } \\
\hline & & & \multicolumn{4}{|c|}{ Oil (MMBO) } & \multicolumn{4}{|c|}{ Gas (BCFG) } & \multicolumn{4}{|c|}{ NGL (MMBNGL) } \\
\hline & & & F95 & F50 & F5 & Mean & F95 & F50 & F5 & Mean & F95 & F50 & F5 & Mean \\
\hline \multicolumn{15}{|c|}{ Upper Jurassic-Cretaceous-Tertiary Composite Total Petroleum System } \\
\hline Eagle Ford Marl Continuous Oil AU & 1.0 & Oil & 3,397 & 4,962 & 7,443 & 5,129 & 5,689 & 9,810 & 16,328 & 10,240 & 100 & 192 & 354 & 205 \\
\hline $\begin{array}{l}\text { Submarine Plateau-Karnes Trough Continuous } \\
\text { Oil AU }\end{array}$ & 1.0 & Oil & 77 & 178 & 302 & 182 & 223 & 526 & 941 & 546 & 6 & 15 & 30 & 16 \\
\hline $\begin{array}{l}\text { Cenomanian-Turonian Mudstone Continuous } \\
\text { Oil AU }\end{array}$ & 1.0 & Oil & 1,792 & 3,064 & 5,101 & 3,204 & 3,134 & 6,008 & 11,037 & 6,412 & 56 & 118 & 236 & 128 \\
\hline Total undiscovered continuous oil resources & & & 5,266 & 8,204 & 12,846 & 8,515 & 9,046 & 16,344 & 28,306 & 17,198 & 162 & 325 & 620 & 349 \\
\hline Eagle Ford Marl Continuous Gas AU & 1.0 & Gas & & & & & 21,922 & 34,303 & 52,061 & 35,304 & 614 & 1,019 & 1,634 & 1,057 \\
\hline $\begin{array}{l}\text { Submarine Plateau-Karnes Trough Continuous } \\
\text { Gas AU }\end{array}$ & 1.0 & Gas & & & & & 5,908 & 7,943 & 10,843 & 8,100 & 224 & 316 & 449 & 324 \\
\hline $\begin{array}{l}\text { Cenomanian-Turonian Mudstone Continuous } \\
\text { Gas AU }\end{array}$ & 1.0 & Gas & & & & & 1,108 & 4,464 & 12,838 & 5,379 & 32 & 132 & 390 & 161 \\
\hline $\begin{array}{l}\text { Cenomanian-Turonian Downdip Continuous } \\
\text { Gas AU }\end{array}$ & & Gas & \multicolumn{12}{|c|}{ Not quantitatively assessed } \\
\hline Total undiscovered continuous gas resources & & & & & & & 28,938 & 46,710 & 75,742 & 48,783 & 870 & 1,467 & 2,473 & 1,542 \\
\hline Total undiscovered continuous resources & & & 5,266 & 8,204 & 12,846 & 8,515 & 37,984 & 63,054 & 104,048 & 65,981 & 1,032 & 1,792 & 3,093 & 1,891 \\
\hline
\end{tabular}

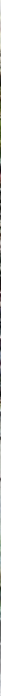

Upper Eagle Ford Group at Lozier Canyon, near Del Rio, Texas. Photograph by Stanley T. Paxton, U.S. Geological Survey. 


\section{References Cited}

Coleman, J.L., Milici, R.C., Cook, T.A., Charpentier, R.R., Kirschbaum, M., Klett, T.R., Pollastro, R.M., and Schenk, C.J., 2011, Assessment of undiscovered oil and gas resources of the Devonian Marcellus Shale of the Appalachian Basin Province, 2011: U.S. Geological Survey Fact Sheet 2011-3092, 2 p., accessed May 29, 2018, at https://pubs.usgs.gov/fs/2011/3092.

Denne, R.A., and Breyer, J.A., 2016, Regional depositional episodes of the Cenomanian-Turonian Eagle Ford and Woodbine Groups of Texas, in Breyer, J.A., ed., The Eagle Ford Shale-A renaissance in U.S. oil production: American Association of Petroleum Geologists, Memoir 110, p. 87-133.

Donovan, A.D., Evenick, J., Banfield, L., McInnis, N., and Hill, W., 2017, An organofacies-based mudstone classification for unconventional tight rock and source rock plays - Unconventional Resources Technology Conference, Austin, Tex., July 24-26, 2017, Proceedings: Society of Exploration Geophysicists, American Association of Petroleum Geologists, Society of Petroleum Engineers, Paper URTeC-2715154-MS, p. 3683-3697, accessed June 5, 2018, at http://archives.datapages.com/data/urtec/2017/2715154.pdf.

Donovan, A.D., Gardner, R.D., Pramudito, A., Staerker, T.S., Wehner, M., Corbett, M.J., Lundquist, J.J., Romero, A.M., Henry, L.C., Rotzien, J.R., and Boling, K.S., 2015, Chronostratigraphic relationships of the Woodbine and Eagle Ford Groups across Texas: Gulf Coast Association of Geological Societies (GCAGS), GCAGS Journal, v. 4, p. 67-87.

Dubiel, R.F., Pearson, O.N., Pitman, J.K., Pearson, K.M., and Kinney, S.A., 2012, Geology and sequence stratigraphy of undiscovered oil and gas resources in conventional and continuous petroleum systems in the Upper Cretaceous Eagle Ford Group and related strata, U.S. Gulf Coast region: Gulf Coast Association of Geological Societies Transactions, v. 62, p. 57-72.

Galloway, W.E., 2008, Depositional evolution of the Gulf of Mexico sedimentary basin, chap. 15 of Miall, A.D., ed., Sedimentary basins of the United States and Canada: Elsevier, Sedimentary Basins of the World, v. 5, p. 505-549.

Gaswirth, S.B., Marra, K.R., Cook, T.A, Charpentier, R.R., Gautier, D.L., Higley, D.K., Klett, T.R., Lewan, M.D., Lillis, P.G., Schenk, C.J., Tennyson, M.E., and Whidden, K.J., 2013, Assessment of undiscovered oil resources in the Bakken and Three Forks Formations, Williston Basin Province, Montana, North Dakota, and South Dakota, 2013: U.S. Geological Survey Fact Sheet 2013-3013, 4 p., accessed May 29, 2018, at https://pubs.usgs.gov/fs/2013/3013.

Gaswirth, S.B., Marra, K.R., Lillis, P.G., Mercier, T.J., Leathers-Miller, H.M., Schenk, C.J., Klett, T.R., Le, P.A., Tennyson, M.E., Hawkins, S.J., Brownfield, M.E., Pitman, J.K., and Finn, T.M., 2016, Assessment of undiscovered continuous oil resources in the Wolfcamp shale of the Midland Basin, Permian Basin Province, Texas, 2016: U.S. Geological Survey Fact Sheet 2016-3092, 4 p., accessed May 29, 2018, at https://doi.org/10.3133/fs20163092.
Hammes, U., Eastwood, R., McDaid, G., Vankov, E., Gherabati, S.A., Smye, K., Shultz, J., Potter, E., Ikonnikova, S., and Tinker, S., 2016, Regional assessment of the Eagle Ford Group of south Texas, USA - Insights from lithology, pore volume, water saturation, organic richness, and productivity correlations: Interpretation, v. 4, no. 1, p. SC125-SC150.

Hawkins, S.J., Charpentier, R.R., Schenk, C.J., Leathers-Miller, H.M., Klett, T.R., Brownfield, M.E., Finn, T.M., Gaswirth, S.B., Marra, K.R., Le, P.A., Mercier, T.J., Pitman, J.K., and Tennyson, M.E., 2016, Assessment of continuous (unconventional) oil and gas resources in the Late Cretaceous Mancos Shale of the Piceance Basin, Uinta-Piceance Province, Colorado and Utah, 2016: U.S. Geological Survey Fact Sheet 2016-3030, 4 p., accessed May 29, 2018, at https://doi.org/10.3133/fs20163030.

Kirschbaum, M.A., Schenk, C.J., Cook, T.A., Ryder, R.T., Charpentier, R.R., Klett, T.R., Gaswirth, S.B., Tennyson, M.E., and Whidden, K.J., 2012, Assessment of undiscovered oil and gas resources of the Ordovician Utica Shale of the Appalachian Basin Province, 2012: U.S. Geological Survey Fact Sheet 2012-3116, 6 p., accessed May 29, 2018, at https://pubs.usgs.gov/fs/2012/3116.

Marra, K.R., Charpentier, R.R., Schenk, C.J., Lewan, M.D., LeathersMiller, H.M., Klett, T.R., Gaswirth, S.B., Le, P.A., Mercier, T.J., Pitman, J.K., and Tennyson, M.E., 2015, Assessment of undiscovered shale gas and shale oil resources in the Mississippian Barnett Shale, Bend Arch-Fort Worth Basin Province, north-central Texas: U.S. Geological Survey Fact Sheet 2015-3078, 2 p., accessed May 29, 2018, at https://doi.org/10.3133/fs20153078.

Marra, K.R., Gaswirth, S.B., Schenk, C.J., Leathers-Miller, H.M., Klett, T.R., Mercier, T.J., Le, P.A., Tennyson, M.E., Finn, T.M., Hawkins, S.J., and Brownfield, M.E., 2017, Assessment of undiscovered oil and gas resources in the Spraberry Formation of the Midland Basin, Permian Basin Province, Texas, 2017: U.S. Geological Survey Fact Sheet 2017-3029, 2 p., accessed May 29, 2018, at https://doi.org/10.3133/fs20173029.

Paxton, S.T., Pitman, J.K., Kinney, S.A., Gianoutsos, N.J., Pearson, O.N., Whidden, K.J., Dubiel, R.F., Schenk, C.J., Burke, L.A., Klett, T.R., Leathers-Miller, H.M., Mercier, T.J., Haines, S.S., Varela, B.A., Le, P.A., Finn, T.M., Gaswirth, S.B., Hawkins, S.J., Marra, K.R., and Tennyson, M.E., 2017a, Assessment of undiscovered oil and gas resources in the Bossier Formation, U.S. Gulf Coast, 2016: U.S. Geological Survey Fact Sheet 2017-3015, 2 p., accessed May 29, 2018, at https://doi.org/10.3133/fs20173015.

Paxton, S.T., Pitman, J.K., Kinney, S.A., Gianoutsos, N.J., Pearson, O.N., Whidden, K.J., Dubiel, R.F., Schenk, C.J., Burke, L.A., Klett, T.R., Leathers-Miller, H.M., Mercier, T.J., Haines, S.S., Varela, B.A., Le, P.A., Finn, T.M., Gaswirth, S.B., Hawkins, S.J., Marra, K.R., and Tennyson, M.E., 2017b, Assessment of undiscovered oil and gas resources in the Haynesville Formation, U.S. Gulf Coast, 2016: U.S. Geological Survey Fact Sheet 2017-3016, 2 p., accessed May 29, 2018, at https://doi.org/10.3133/fs20173016.

Banner image shows organic-rich (darker) interval in the lower Eagle Ford Group at Lozier Canyon, near Del Rio, Texas. Photograph by Stanley T. Paxton, U.S. Geological Survey.

\section{Eagle Ford Group Assessment Team}

Katherine J. Whidden, Janet K. Pitman, Ofori N. Pearson, Stanley T. Paxton, Scott A. Kinney, Nicholas J. Gianoutsos, Christopher J. Schenk, Heidi M. Leathers-Miller, Justin E. Birdwell, Michael E. Brownfield, Lauri A. Burke, Russell F. Dubiel, Katherine L. French, Stephanie B. Gaswirth, Seth S. Haines, Phuong A. Le, Kristen R. Marra, Tracey J. Mercier, Marilyn E. Tennyson, and Cheryl A. Woodall

\section{For More Information}

Assessment results are also available at the USGS Energy Resources Program website at https://energy.usgs.gov. 